\title{
Scope of Conventional and Fractal Morphometry in Oral Potentially Malignant Disorders and Oral Cancer
}

\author{
Paresh Kumar Behera', Diksha Mohapatra ${ }^{2}$ \\ ${ }^{1}$ Assistant Professor, Department of Head \& Neck Oncology, Acharya Harihar Post Graduate \\ Institute of Cancer, Cuttack, Odisha, India \\ ${ }^{2}$ Post Graduate Trainee, Department of Oral Pathology and Microbiology, Institute of Dental \\ Sciences, Siskha $O$ Anusandhan (Deemed to be University), Bhubaneswar, Odisha, India
}

Article Info: Received 15 September 2021; Accepted 29 October 2021

DOI: https://doi.org/10.32553/jbpr.v10i6.890

Corresponding author: Diksha Mohapatra

Conflict of interest statement: No conflict of interest

\begin{abstract}
World Health Organization (WHO) defined the terminology 'Oral Potentially malignant disorders' (OPMD) as the presence of risk of malignancy in a lesion or condition either during the time of initial diagnosis or at a future date with the commonly accepted prevalence of $1-5 \%$. All OPMDs may not transform into malignancy, many factors have been explored which effectively assess the risk of malignant transformation in OPMDs including many clinical, pathological and molecular factors. Qualitative \& experimental factors of different cells in cytological preparations and/or biopsy specimens are reliable parameters for pathologists. The analysis and assessment of histological units can be enhanced by image analysis assisted by a computer that can be used for statistical comparisons. Fractal geometry is considered to be an ideal method of image analysis in quantitative microscopy \& histopathology. Fractal dimension analysis is not only limited to determining cell and tumour types but can also be used for determining cellular behaviours in vitro such as cell migration, apoptosis and cellular differentiation, which can be a useful characterization of oral cancer lines and further help in the treatment planning.
\end{abstract}

Keywords: Oral Cancer, Oral Potentially Malignant Disorders (OPMDs), Conventional morphometry, Fractal Dimension, Photomicrograph

\section{Introduction}

World Health Organization (WHO) defined the terminology 'Oral Potentially malignant disorders' (OPMD) as the presence of risk of malignancy in a lesion or condition either during the time of initial diagnosis or at a future date with the commonly accepted prevalence of 1$5 \%$. (1) Early diagnosis of OPMDs and OSCC can increase survival which may be achieved by both non-invasive and invasive techniques.
However, pathologists diverge in the importance they give to particular histopathologic features and the interpretation of dysplasia varies from one pathologist to another. The wide subjective variation has always sought the necessity of objective means of evaluation(2,3). Recently with the upcoming trends in cytomorphometry and histomorphometry focus on the direction of the diagnostic potential of these techniques in OPMDs and OSCC has been emphasized which 
may reduce the subjective variation to a great extent.

A prognostic factor is a clinical or biological feature that is objectively measurable and that gives information on the possible outcome of the disease in an untreated person. All OPMDs may not transform into malignancy, many factors have been explored which effectively assess the risk of malignant transformation in OPMDs including many clinical, pathological and molecular factors. Clinical factors include gender, duration, location, size and nature of the lesion whereas histopathological factors include the presence of dysplasia, DNA ploidy, loss of heterozygosity $(\mathrm{LOH})$ and genes are the molecular factors. (4) Irrespective of histological dysplastic grading, strong evidence suggests that finding of very similar variations in diseases like leukoplakia and erythroplakia are closely linked to neoplastic transformation risk. (5-9). Likewise in 14 out of 42 (33\%) cases of oral dysplasia aneuploidy was seen that progressed \& 5 out of 44 (11\%) cases showed no progression. (10)

A large-scale retrospective study was done in recent times that established dysplasia and aneuploidy can be seen as independent predictive factors for malignant transformation. (10) Many studies were done that demonstrated high-frequency LOH which occurs on $3 p$ and $9 p$ are strongly associated with leukoplakia transformation and the progression or recurrence of oral cancer(11-17). The role of p53 (TP53) has been also established in the malignant transformation potential of $\operatorname{OPMDs}(18,19)$. Cervical lymph node metastasis, five-year survival, recurrence are a few well-established prognostic factors in patients diagnosed with OSCC (20-23). A discrete relationship is present between the number \& level of cervical lymph nodes metastasized with the epithelial cell and five-year survival (24). Clinical neck dissection has an estimated sensitivity of $75 \%$ $82 \%$ and specificity of $80 \%-83 \%(25,26)$. Evidence of cervical lymph node metastasis is well acknowledged by neck dissection and it's undertaken based on clinical node involvement, the experience of the surgeon with consideration of other predictive and prognostic factors.

Attempts are made for many years to define the parameters and classifications that may enable to segregate the patients into groups of low, intermediate and high risk. Definite factors have been implied like TNM staging, histopathologic malignancy grading system,(27-34) interactions between stroma and invasive tumour front,(3539) lymph vascular invasion,(40-43), perineural infiltration, $(40,41,43)$, tumour thickness and compromised margins $(44,45)$. A debatable role of the predictive value of proliferation markers in OSCC also exists $(30,46-54)$. However, the utility of these prognostic factors in OPMDs and OSCC has been restricted mostly dues to their semi-quantitative nature and subjective variation. In order to overcome these limitations computers assisted morphometric analysis has emerged as an alternative approach to measure the cellular and nuclear features which further may be correlated with the outcome of OPMDs and OSC.

\section{COMPUTER-ASSISTED MORPHOMETRIC ANALYSIS}

Qualitative \& experimental factors of different cells in cytological preparations and/or biopsy specimens are reliable parameters for pathologists. Many empirical methods have been backed up by morphometry like an estimation of the surface area, volume, axis ratios, calculation of density of population and various methods which are derived from Euclidean geometry. They find their application to assess the nucleus, nucleoli present, chromatin quantity, abnormalities in the nuclear membrane, perturbations in the cytoplasmic membrane and differentiation degree. Since time immemorial it has been under consideration in mathematics \& physical sciences that concepts of Euclidean geometry like length, perimeter, volume or surface area do not give definite answers related to certain objects. The analysis and assessment of histological units can be enhanced by image analysis assisted by a computer that can be used for statistical 
comparisons. The advantages of computerassisted morphometric image analysis are-

i. Quantitative or semi-quantitative description of pathologists' qualitative assessment of cellular architecture.

ii. This objective estimation is not exaggerated by intraobserver or inter-examiner variability.

These advantages combinedly shall have a meaningful predictive value. The morphometry can be studied by conventional and modern methods.

Conventional morphometry, a concept derived from Euclidean geometry has been applied in computer-assisted histopathology image analysis to correlate the size and shape of cell/ nucleus with clinical outcome in cancer. This method has studied its application assuming ideal and regular geometrical shapes of cells. But to great dismay, the chaotic growth in cancer leads to the irregular surface area, uneven contour length and other complex dimensional parameters making the application of conventional morphometry unacceptable. There are some inherent microscopic aberrations in cellular architecture which are neither obvious nor easily appreciated by conventional semiquantitative morphometric analysis of images. This necessitates the invention of the Fractal dimension and its applicability in cancer.

Recent computational progress related to the field of spatial statistics, artificial nerve network permits the description of cell and nuclear shape irregularity with respect to abnormal chaotic growth in cancer. Chief characteristics of the morphologic complexity of normal \& abnormal cells $\&$ tissues are variations under scale such as irregularity \& self-similarity. No change is seen in the form of a self-similar entity if the measurement scale changes as every part look like the original entity. Minute details and variations in the size \& geometrical parameters of an asymmetrical entity are seen upon examining at high resolution. Conventional morphometry uses a single arbitrary measuring scale to analyze the reductive representation or unrealistic approximation of cellular and nuclear irregularities.

\section{MODERN MORPHOMETRY - FRACTAL DIMENSION}

Fractal geometry(55) is considered to be an ideal method of image analysis in quantitative microscopy \& histopathology(56-60). A sumptuous number of studies have claimed a probable link present between cancer \& fractals(56-58). It was stated that the imbalance consisting of diverse biological \& chemical reactions is usually related to cancer which could result in chaos and the consequent appearance of fractal geometry. Neoplastic cells lose the ability to control their growth which results in a change in shape. Every cell has a particular fractal geometry which can be called the marker for that type. By using this fractalmathematical technique along with enhanced and sophisticated picture recognition, we can institute the multi sequential progression of carcinoma in a cell. Statistical intensity \& distribution of irregularities present in the cell contour can be measured by Fractal dimension analysis. Fractal nature is demonstrated more by neoplastic cells than the healthy cells because the disordered growth shown by tumors cause uneven convexities of different size over the surface of cell. Fractal dimension helps researchers in the identification of occurrence of tumor cell and to establish with $97 \%$ accuracy as to evaluate two different lines of neoplastic pancreas cancer cells to which it belongs.

As told by Joachim Spatz, Fractal dimension analysis is a more accurate, precise \& quicker method to determine the cell type of cancer than the conventional procedure. Fractal nature is one of the fascinating patterns in nature seen as 'selfsimilar' irregular curves or shapes that repeat their pattern when magnified in or out. Being said, fractal patterns are shaped under far-fromequilibrium circumstances or come out from the chaos. The examples of patterns showing fractality range from large scale entities of the universe to the geometry of various biological tissues. Intricate structures in biology do not have definite length and quite often they have 
properties of fractal or show scaling properties. Moreover, the structures with fractal nature have profound importance in the human body. To facilitate the gaseous exchanges at the interface of vasculature and alveolar surface, selfsimilarity of the trachea $\&$ bronchi tree offer a vast surface area, coupling of pulmonary \& cardiac functions, \& fractal branching gives a vast network for the supply of nutrients \& oxygen as well for metabolic waste products collection. The fractal arrangement of connective tissue in aortic leaflets provides functions facilitating the proficient circulation of mechanical forces.

Mandelbrot stated that this can be grouped by index like the "fractal dimension" D, which is an analysis of the geometrical complexity \& the space-filling properties of a structure. Later on, fractal dimension analysis entered into various parts like pathology, differential diagnosis, prognosis \& treatment of the patients. Internal membrane surface of cells or inner lung surface demonstrate properties of fractal geometry section-wise and within certain limits set by deterministic design properties and are a bit tricky to be explained in the terms of classical geometry. This is where the understanding and application concepts of fractal geometry are most beneficial. The phrase Fractal derived from the Latin adjective 'fractus' which means irregular or fragmented comes from the Latin verb 'frangere' which means a break or segregate into irregular fragments as coined by Mandelbrot. Biological \& natural objects to be described as fractals must accomplish a specific number of theoretical \& methodological parameters as well as a high level of organization, irregularity in shape, functional, morphological \& temporal similarity, invariance in scale, iterative pathways \& a non-integer fractal dimension.

Mathematical objects are deterministic invariant $\&$ self-similar in a wide range of scales and biological components \& morphological structures are self-similar within a domain called "scaling window," i.e., only within this particular window, the fractal properties of an irregular object of finite dimension can be seen. Biological \& morphological entities require experimental recognition for each of their elements \& the scale range has to account for a minimum of 2 orders of magnitude. Principles of fractal and its usage are important to measure dimension properties and spatial measures of biological entities which are irregular which will enable us to a precise understanding of the architectural \& morphological organization of tissues and organs, \& assess the contrast among delicate morphogenetic changes that occur during the development \& progression of physiological, pathologic, and neoplastic processes. Fractal geometry permits structures to objectively quantify the geometric parameter of cell and other tissue architecture even if their form is irregular. Hence, it helps to clarify the doubt of internal gaseous exchange at the surface of the lungs which is homogenous; competently ventilated \& perfusion takes place at a low energetic cost. It can now be ascertained that the fractal principle of biological design is heuristically empirical \& gives insight into the possibilities of a well-organized genetic study \& programming of its outline.

In the world of fractal geometry, the notion of dimension corresponds to 1 for curve, 2 for a surface \& 3 for a solid which may seem to be strange but this extension is pretty natural. It is usually anticipated that the number of boxes required to cover a given surface shall be more if boxes that are smaller in size are used. Considering planar entities, it is supposed that when boxes which are $1 / 3^{\text {rd }}$ of their width if used then the number of boxes needed to cover the given object $(\mathrm{N})$ shall be 9 times greater or if stated in equation form, $N\}$ L22, wherein $\mathrm{L}$ is the width of the box. If in place of a simple, compact entity we calculate the number of boxes required to cover the fractal, we can see that every time the size of the box is decreased by $1 / 3 \mathrm{rd}$, we shall require 8 (not the expected 9) times as many boxes. We come to know that the quantity boxes required increases slowly with an exponent between 1-2 according to the value $\mathrm{N}$ \} L2D. For this particular case we can see a non- 
integer or fractal dimension (D $5 \log (8) / \log (1 / 3)$

$>1.89)$.(56)

We have compiled the evidence of the diagnostic and prognostic utility of conventional as well as fractal geometry in potentially malignant and malignant oral disorders.
A detailed analysis of articles related to conventional morphometry in OPMD \& OSCC published only in journals indexed in PUBMED has been tabulated in table 1 .

Table 1: Available data on conventional morphometry in OPMD \& OSCC.

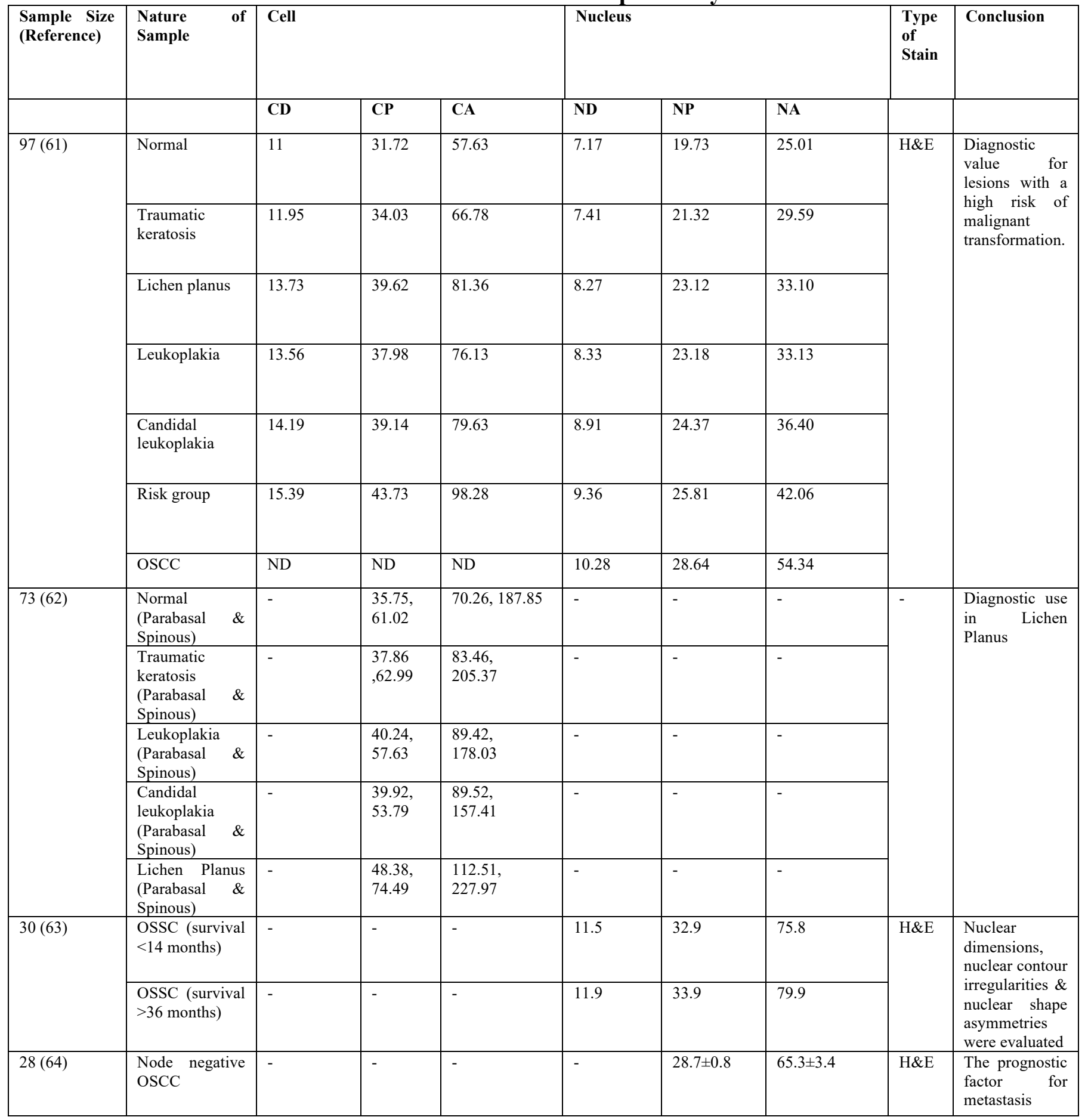




\begin{tabular}{|c|c|c|c|c|c|c|c|c|c|}
\hline & $\begin{array}{l}\text { Node positive } \\
\text { OSCC }\end{array}$ & - & - & - & - & $36.6 \pm 1.3$ & $100.4 \pm 5.9$ & & \\
\hline $30(65)$ & OSCC & & - & - & $\begin{array}{l}12.8 \pm 2 \\
(73.33)\end{array}$ & $\begin{array}{l}438 \pm 150 \\
(70)\end{array}$ & $80 \pm 30(66.67)$ & $\mathrm{H} \& \mathrm{E}$ & $\begin{array}{l}\text { Predictor of } \\
\text { survival. }\end{array}$ \\
\hline \multirow[t]{2}{*}{$16(66)$} & $\begin{array}{l}\text { Node negative } \\
\text { OSCC }\end{array}$ & - & - & - & - & 3.607 & 77.997 & \multirow[t]{2}{*}{$\mathrm{H} \& \mathrm{E}$} & \multirow{2}{*}{$\begin{array}{l}\text { Prediction of } \\
\text { nodal } \\
\text { metastases in } \\
\text { OSCC. }\end{array}$} \\
\hline & $\begin{array}{l}\text { Node positive } \\
\text { OSCC }\end{array}$ & - & - & - & - & 3.759 & 81.701 & & \\
\hline \multirow[t]{4}{*}{$60(67)$} & $\begin{array}{l}\text { Normal gingiva } \\
\text { (Parabasal \& } \\
\text { Spinous) }\end{array}$ & $\begin{array}{l}15.91 \pm 1.79 \\
19.07 \pm 4.40\end{array}$ & - & $\begin{array}{l}187 \pm 43.11 \\
241.04 \pm 67.08\end{array}$ & $\begin{array}{l}8.39 \pm 0.78 \\
9.35 \pm 4.53\end{array}$ & - & $\begin{array}{l}57.05 \pm 10.40 \\
58.74 \pm 10.94\end{array}$ & \multirow[t]{4}{*}{ H\&E } & \multirow{4}{*}{$\begin{array}{l}\text { Nuclear } \\
\text { parameters } \\
\text { showed a } \\
\text { statistically } \\
\text { significant } \\
\text { change than } \\
\text { cellular } \\
\text { parameters in } \\
\text { dysplasia. }\end{array}$} \\
\hline & $\begin{array}{l}\text { Normal Buccal } \\
\text { mucosa } \\
\text { (Parabasal \& } \\
\text { Spinous) }\end{array}$ & $\begin{array}{l}14.75 \pm 1.16 \\
17.35 \pm 1.73\end{array}$ & & $\begin{array}{l}159.27 \pm 20.92 \\
226.9 \pm 35.89\end{array}$ & $\begin{array}{l}7.84 \pm 0.71 \\
8.39 \pm 0.79\end{array}$ & & $\begin{array}{l}50.13 \pm 10.31 \\
56.51 \pm 10.88\end{array}$ & & \\
\hline & $\begin{array}{l}\text { Leukoplakia on } \\
\text { buccal mucosa } \\
\text { (Parabasal \& } \\
\text { Spinous) }\end{array}$ & $\begin{array}{l}17.60 \pm 2.91 \\
17.60 \pm 2.91\end{array}$ & & $\begin{array}{l}230.78 \pm 72.50 \\
230.78 \pm 72.50\end{array}$ & $\begin{array}{l}9.40 \pm 1.28 \\
9.40 \pm 1.28\end{array}$ & & $\begin{array}{l}73.29 \pm 16.92 \\
73.29 \pm 16.92\end{array}$ & & \\
\hline & $\begin{array}{ll}\begin{array}{l}\text { Leukoplakia } \\
\text { gingiva }\end{array} & \\
\text { (Parabasal } \& \\
\text { Spinous) }\end{array}$ & $\begin{array}{l}15.99 \pm 2.60 \\
18.62 \pm 2.37\end{array}$ & & $\begin{array}{l}189.09 \pm 61.03 \\
243.99 \pm 62.14\end{array}$ & $\begin{array}{l}9.11 \pm 0.95 \\
9.64 \pm 1.08\end{array}$ & & $\begin{array}{l}68.28 \pm 10.25 \\
77.25 \pm 12.78\end{array}$ & & \\
\hline \multirow[t]{4}{*}{$60(68)$} & Normal & - & - & - & - & $29.4 \pm 1.5$ & $69.7 \pm 6.3$ & \multirow[t]{4}{*}{$\begin{array}{l}\text { Feulg } \\
\text { en }\end{array}$} & \multirow{4}{*}{$\begin{array}{l}\text { A reliable tool } \\
\text { for grading } \\
\text { OSCC. }\end{array}$} \\
\hline & $\begin{array}{l}\text { Well- } \\
\text { differentiated } \\
\text { OSCC }\end{array}$ & - & - & - & - & $38.5 \pm 3.2$ & $111.4 \pm 15.1$ & & \\
\hline & $\begin{array}{l}\text { Moderately } \\
\text { differentiated } \\
\text { OSCC }\end{array}$ & - & - & - & - & $39.2 \pm 2.9$ & $116.6 \pm 20.7$ & & \\
\hline & $\begin{array}{l}\text { Poorly } \\
\text { differentiated } \\
\text { OSCC }\end{array}$ & - & - & - & - & $41.1 \pm 2.9$ & $122.8 \pm 15.5$ & & \\
\hline \multirow[t]{3}{*}{$70(69)$} & Leukoplakia & - & 48.3146 & 123.4443 & - & 34.2598 & 59.40263 & \multirow[t]{3}{*}{$\mathrm{IHC}$} & \multirow{3}{*}{$\begin{array}{l}\text { Differentiation } \\
\text { between } \\
\text { normal, } \\
\text { leukoplakia } \\
\text { and OSCC }\end{array}$} \\
\hline & $\begin{array}{l}\text { Well- } \\
\text { differentiated } \\
\text { OSCC } \\
\end{array}$ & - & 52.9577 & 153.6086 & - & 40.09 & 74.47 & & \\
\hline & $\begin{array}{l}\text { Normal buccal } \\
\text { mucosa }\end{array}$ & - & 30.4278 & 77.86 & - & 18.2369 & 27.0177 & & \\
\hline \multirow[t]{3}{*}{$25(70)$} & $\begin{array}{l}\text { Normal oral } \\
\text { mucosa (Basal } \\
\& \text { suprabasal) }\end{array}$ & - & - & $\begin{array}{l}26.8001 \\
35.6096\end{array}$ & $\begin{array}{l}4.0649, \\
4.3477\end{array}$ & - & $\begin{array}{l}13.2374 \\
15.1712\end{array}$ & \multirow[t]{3}{*}{$\mathrm{H} \& \mathrm{E}$} & \multirow{3}{*}{$\begin{array}{l}\text { Discrimination } \\
\text { between } \\
\text { normal and } \\
\text { premalignant } \\
\text { lichen planus } \\
\text { and lichenoid } \\
\text { lesions. }\end{array}$} \\
\hline & $\begin{array}{l}\text { Oral lichenoid } \\
\text { lesion (Basal \& } \\
\text { suprabasal) }\end{array}$ & - & & $\begin{array}{l}33.9658, \\
43.1726\end{array}$ & $\begin{array}{l}4.3225, \\
4.7374\end{array}$ & - & $\begin{array}{l}15.2688 \\
18.4352\end{array}$ & & \\
\hline & $\begin{array}{l}\text { Oral lichen } \\
\text { planus (Basal \& } \\
\text { suprabasal) }\end{array}$ & - & & $\begin{array}{l}35.8542, \\
46.9928\end{array}$ & $\begin{array}{l}4.4517 \\
4.7651\end{array}$ & - & $\begin{array}{l}16.4556, \\
18.7684\end{array}$ & & \\
\hline \multirow[t]{4}{*}{$70(71)$} & Normal mucosa & - & - & - & $3.48 \pm 0.81$ & - & $9.30 \pm 2.04$ & \multirow{4}{*}{$\begin{array}{l}\text { Feulg } \\
\text { en }\end{array}$} & \multirow{4}{*}{$\begin{array}{l}\text { Differentiation } \\
\text { of grades of } \\
\text { dysplasia }\end{array}$} \\
\hline & Mild dysplasia & - & - & - & $4.86 \pm 1.10$ & - & $18.90 \pm 5.24$ & & \\
\hline & $\begin{array}{l}\text { Moderate } \\
\text { dysplasia }\end{array}$ & - & - & - & $4.90 \pm 1.11$ & - & $19.36 \pm 5.75$ & & \\
\hline & $\begin{array}{l}\text { Severe } \\
\text { dysplasia }\end{array}$ & - & - & - & $5.29 \pm 1.42$ & - & $22.21 \pm 8.70$ & & \\
\hline
\end{tabular}




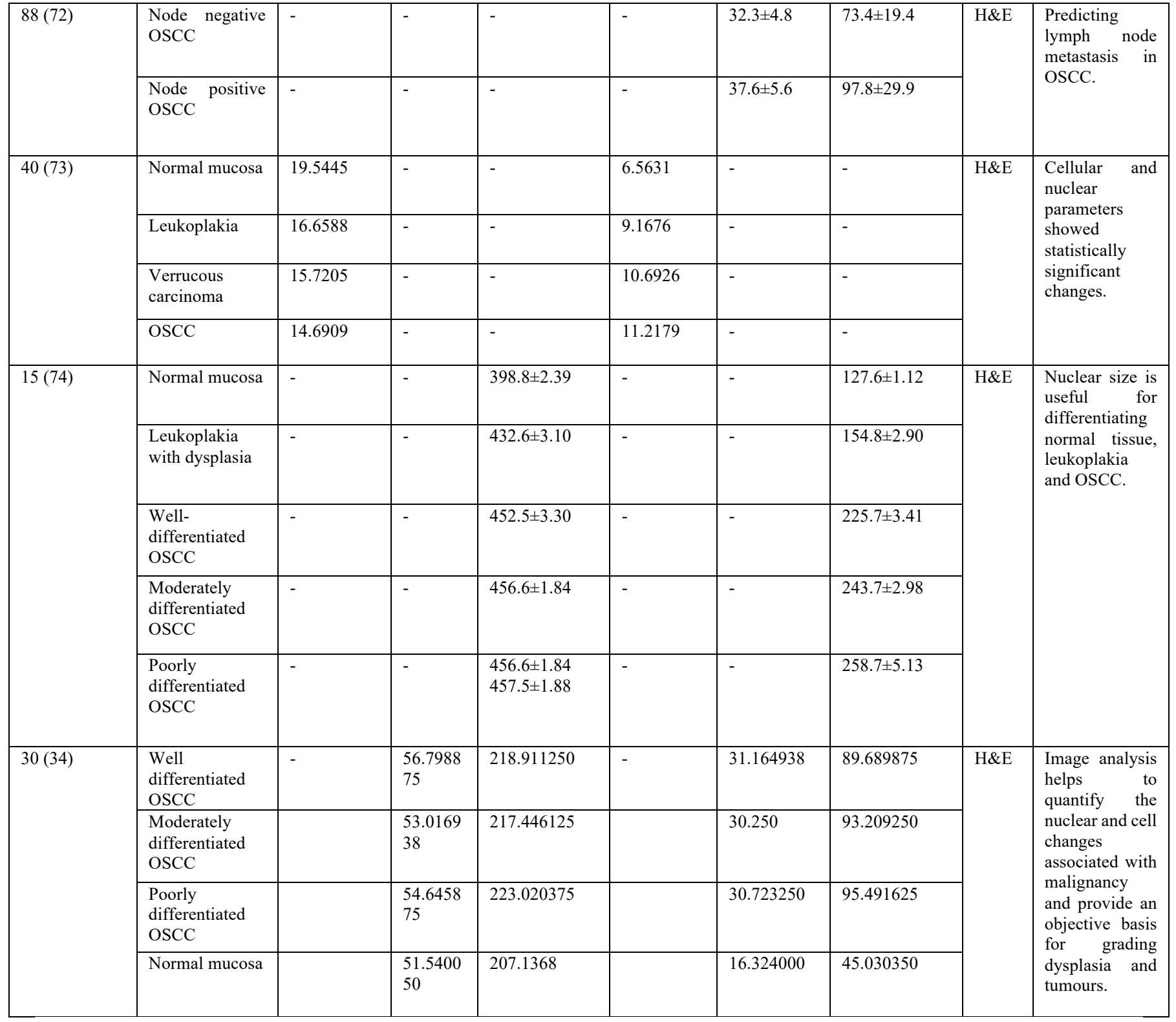

CD- cell diameter, CP- cell perimeter, CA- cell area, ND- nuclear diameter, NP- nuclear perimeter, NA- nuclear area

FRACTAL DIMENSION IN ORAL POTENTIALLY MALIGNANT DISORDERS AND ORAL SQUAMOUS CELL CARCINOMA

All studies conducted to evaluate the prognostic role of nFD in oral cancer were summarized in table 2 .

Table 2: Prognostic role of nFD in oral cancer.

\begin{tabular}{|c|c|c|c|}
\hline AUTHOR & $\begin{array}{l}\text { SAMPLE } \\
\text { SIZE (N) }\end{array}$ & STAINS & PROGNOSTIC ROLE OF NFD \\
\hline $\begin{array}{l}\text { Yinti et al., } \\
2015\end{array}$ & 14 & H \& E, Feulgen & $\begin{array}{l}\text { Low nFD - increased survival } \\
\text { Histological grading }\end{array}$ \\
\hline
\end{tabular}




\begin{tabular}{|l|l|l|l|}
\hline & & & Staging \\
\hline $\begin{array}{l}\text { Phulari et al., } \\
2016\end{array}$ & 60 & H \& E & $\begin{array}{l}\text { Distinguish between normal mucosa, } \\
\text { dysplasia and carcinoma }\end{array}$ \\
\hline $\begin{array}{l}\text { Mincione et al., } \\
2015\end{array}$ & 64 & H \& E, Feulgen & $\begin{array}{l}\text { Staging } \\
\text { Grading } \\
\text { Low nFD - increased survival }\end{array}$ \\
\hline $\begin{array}{l}\text { Goutzanis et } \\
\text { al., 2007 }\end{array}$ & H \& E, Feulgen & $\begin{array}{l}\text { Carcinoma presented higher mean } \\
\text { values of FD compared to normal } \\
\text { mucosa. } \\
\text { lowFD - increased survival }\end{array}$ \\
\hline $\begin{array}{l}\text { Bose et al., } 107 \\
2015\end{array}$ & $\begin{array}{l}\text { 4',6-diamidino-2- } \\
\text { phenylindole (DAPI) }\end{array}$ & $\begin{array}{l}\text { Pathological tumour-stage } \\
\text { Radiation treatment. } \\
\text { High nFD of the total tumour } \\
\text { microenvironment (stroma plus tumour) } \\
\text { with improved disease-specific survival }\end{array}$ \\
\hline
\end{tabular}

\section{Discussion}

Histopathological evaluation of the lesion is the critical step in the diagnosis of cancer. There occurs significantly inter and intraobserver differences in opinion especially in borderline cases where the wrong diagnosis may misdirect the treatment plan and hence may affect the outcome adversely. The vast expansion of the scope of information technology over the past few decades along with an increase in the incidence of cancer has led to diagnostic medicine amenable to automated computational technology. This will probably lessen the burden of pathologists following the traditional approaches. A three-step process including preprocessing the photomicrograph followed by extraction and analysis of relevant features like fractal dimension, textural features and entropy etc. has proven to diagnose and prognose cancer. We have focused on the fractal dimension as a viable image feature to assess its potential to diagnose malignant oral epithelial cells and predict cervical lymph node metastasis in oral cancer. In cases where sample availability is limited, fractal dimension analysis of nuclei and chromatin can be done, since a miniature amount of tissue is sufficient to determine the phenotype by fractal dimension analysis, which can be compared with conventional pathological methods. (75) Fractal dimension analysis is not only limited to determining cell and tumour types but, can also be used for determining cellular behaviours in vitro such as cell migration, apoptosis and cellular differentiation, which can be the useful characterization of oral cancer lines. (76)

\section{Conclusion}

Oral Cancer is a heterogeneous disease that can be classified into many histological and molecular subtypes. Clinically, Oral cancer can be aggressive in terms of primary tumour growth and metastasis to distant lymph nodes and organs. New tools are required for obtaining a better knowledge of the biology of oral cancer evolution, continuation, and molecular heterogeneity. Fractal-based analyses are multifaceted and sensitive tools that have many potential applications in oral cancer research and diagnosis. Considerable attempts are needed to expand the utility of fractal analysis for investigating the unique anatomy and biology of the oral cavity as well as oral cancer.

\section{References}

1. Vigneswaran $\mathrm{N}$, Williams MD. Epidemiologic trends in head and neck cancer and aids in diagnosis. Oral Maxillofac Surg Clin N Am. 2014 May;26(2):123-41. 
2. DiTroia JF. Nodal metastases and prognosis in carcinoma of the oral cavity. Otolaryngol Clin North Am. 1972 Jun;5(2):333-42.

3. Teichgraeber JF, Clairmont AA. The incidence of occult metastases for cancer of the oral tongue and floor of the mouth: treatment rationale. Head Neck Surg. 1984 Oct;7(1):15-21.

4. Fan K-H, Wang H-M, Kang C-J, Lee L-Y, Huang S-F, Lin C-Y, et al. Treatment results of postoperative radiotherapy on squamous cell carcinoma of the oral cavity: coexistence of multiple minor risk factors results in higher recurrence rates. Int $\mathrm{J}$ Radiat Oncol Biol Phys. 2010 Jul 15;77(4):1024-9.

5. Bryne M, Koppang HS, Lilleng R, Kjaerheim A. Malignancy grading of the deep invasive margins of oral squamous cell carcinomas has high prognostic value. J Pathol. 1992 Apr;166(4):375-81.

6. Anneroth G, Hansen LS, Silverman S. Malignancy grading in oral squamous cell carcinoma. I. Squamous cell carcinoma of the tongue and floor of mouth: histologic grading in the clinical evaluation. J Oral Pathol. 1986 Mar;15(3):162-8.

7. Bryne M, Boysen M, Alfsen CG, Abeler VM, Sudbø J, Nesland JM, et al. The invasive front of carcinomas. The most important area for tumour prognosis? Anticancer Res. 1998 Dec;18(6B):4757-64.

8. Woolgar JA, Scott J. Prediction of cervical lymph node metastasis in squamous cell carcinoma of the tongue/floor of mouth. Head Neck. 1995 Dec;17(6):463-72.

9. Piffkò J, Bànkfalvi A, Ofner D, Bryne M, Rasch D, Joos U, et al. Prognostic value of histobiological factors (malignancy grading and AgNOR content) assessed at the invasive tumour front of oral squamous cell carcinomas. $\mathrm{Br} \quad \mathrm{J} \quad$ Cancer. 1997;75(10):1543-6.

10. Högmo A, Kuylenstierna R, Lindholm J, Munck-Wikland E. Predictive value of malignancy grading systems, DNA content, p53, and angiogenesis for stage I tongue carcinomas. J Clin Pathol. 1999 Jan;52(1):35-40.
11. Welkoborsky HJ, Hinni M, Dienes HP, Mann WJ. Predicting recurrence and survival in patients with laryngeal cancer by means of DNA cytometry, tumor front grading, and proliferation markers. Ann Otol Rhinol Laryngol. 1995 Jul;104(7):503-10.

12. Welkoborsky HJ, Gluckman JL, Jacob R, Bernauer H, Mann W. [Tumor biologic prognostic parameters in T1N0M0 squamous cell carcinoma of the oral cavity]. Laryngorhinootologie.

1999 Mar;78(3):131-8.

13. Hiratsuka H, Imamura M, Ishii Y, Kohama G, Kikuchi K. Immunohistologic detection of lymphocyte subpopulations infiltrating in human oral cancer with special reference to its clinical significance. Cancer. 1984 Jun 1;53(11):2456-66.

14. Gabriel A, Namyslowski G, Ziólkowski A, Morawski K, Steplewska-Mazur K, Urbaniec P. Immunohistochemical analysis of lymphocytic infiltration in the tumor microenvironment in patients operated on for laryngeal cancer. Eur Arch Oto-RhinoLaryngol Off J Eur Fed Oto-Rhino-Laryngol Soc EUFOS Affil Ger Soc Oto-RhinoLaryngol - Head Neck Surg. 1999;256 (8):384-7.

15. Ravi D, Ramadas K, Mathew BS, Nalinakumari KR, Nair MK, Pillai MR. Angiogenesis during tumor progression in the oral cavity is related to reduced apoptosis and high tumor cell proliferation. Oral Oncol. 1998 Nov;34(6):543-8.

16. López-Graniel CM, Tamez de León D, Meneses-García A, Gómez-Ruiz C, FriasMendivil M, Granados-García M, et al. Tumor angiogenesis as a prognostic factor in oral cavity carcinomas. J Exp Clin Cancer Res CR. 2001 Dec;20(4):463-8.

17. Partridge M, Emilion G, Pateromichelakis S, A'Hern R, Lee G, Phillips E, et al. The prognostic significance of allelic imbalance at key chromosomal loci in oral cancer. Br J Cancer. 1999 Apr;79(11-12):1821-7.

18. Chen YW, Yu EH, Wu TH, Lo WL, Li WY, Kao SY. Histopathological factors affecting nodal metastasis in tongue cancer: analysis 
of 94 patients in Taiwan. Int $\mathbf{J}$ Oral Maxillofac Surg. 2008 Oct;37(10):912-6.

19. Suzuki M, Suzuki T, Asai M, Ichimura K-I, Nibu K-I, Sugasawa M, et al. Clinicopathological factors related to cervical lymph node metastasis in a patient with carcinoma of the oral floor. Acta OtoLaryngol Suppl. 2007 Dec;(559):129-35.

20. A A, N H, A B, A N, R J, K J, et al. Development of a New Outcome Prediction Model in Early-stage Squamous Cell Carcinoma of the Oral Cavity Based on Histopathologic Parameters With Multivariate Analysis: The Aditi-Nuzhat Lymph-node Prediction Score (ANLPS) System. Am J Surg Pathol [Internet]. 2017 Jul [cited 2021 Nov 9];41(7). Available from:

https://pubmed.ncbi.nlm.nih.gov/28346327/

21. Adel M, Kao H-K, Hsu C-L, Huang J-J, Lee L-Y, Huang Y, et al. Evaluation of Lymphatic and Vascular Invasion in Relation to Clinicopathological Factors and Treatment Outcome in Oral Cavity Squamous Cell Carcinoma. Medicine (Baltimore). 2015 Oct;94(43):e1510.

22. Wang K, Veivers D. Tumour thickness as a determinant of nodal metastasis in oral tongue carcinoma. ANZ J Surg. 2017 Sep;87(9):720-4.

23. Mücke T, Kanatas A, Ritschl LM, Koerdt S, Tannapfel A, Wolff K-D, et al. Tumor thickness and risk of lymph node metastasis in patients with squamous cell carcinoma of the tongue. Oral Oncol. 2016 Feb;53:80-4.

24. Roland NJ, Caslin AW, Bowie GL, Jones AS. Has the cellular proliferation marker $\mathrm{Ki} 67$ any clinical relevance in squamous cell carcinoma of the head and neck? Clin Otolaryngol Allied Sci. 1994 Feb;19(1):138.

25. Hake R, Eckel H, von Pritzbuer E, Volling $\mathrm{P}$, Thiele J. [Value of monoclonal antibodies (PC 10, MIB1, p53 and LeuM 1) for assessing the prognosis of patients with squamous epithelial carcinoma of the larynx after partial laser resection]. Pathol. 1995 May;16(3):197-203.
26. Kropveld A, Slootweg PJ, Blankenstein MA, Terhaard CH, Hordijk GJ. Ki-67 and p53 in T2 laryngeal cancer. The Laryngoscope. 1998 Oct;108(10):1548-52.

27. p53 mutations, protein expression and cell proliferation in squamous cell carcinomas of the head and neck - PubMed [Internet]. [cited 2021 Nov 9]. Available from: https://pubmed.ncbi.nlm.nih.gov/7710950/

28. [Significance of p53, PCNA and Ki-67 in the prognosis of squamous cell carcinoma of the oral cavity] - PubMed [Internet]. [cited 2021 Nov 9]. Available from: https://pubmed.ncbi.nlm.nih.gov/9213409/

29. The prognostic significance of allelic imbalance at key chromosomal loci in oral cancer - PubMed [Internet]. [cited 2021 Nov 9]. Available from: https://pubmed.ncbi.nlm.nih.gov/10206299/

30. Pich A, Chiusa L, Pisani P, Krengli M, Pia F, Navone R. Argyrophilic nucleolar organizer region counts and proliferating cell nuclear antigen scores are two reliable indicators of survival in pharyngeal carcinoma. J Cancer Res Clin Oncol. 1992;119(2):106-10.

31. Piffkó J, Bánkfalvi A, Ofner D, Kusch F, Böcker W, Joos U, et al. In situ assessment of cell proliferation at the invasive front of oral squamous cell carcinomas. Virchows Arch Int J Pathol. 1996 Nov;429(4-5):229 34.

32. Sittel C, Ruiz S, Volling P, Kvasnicka HM, Jungehülsing $M$, Eckel HE. Prognostic significance of Ki-67 (MIB1), PCNA and p53 in cancer of the oropharynx and oral cavity. Oral Oncol. 1999 Nov;35(6):583-9.

33. Couture $C$, Raybaud-Diogène $H$, Têtu $B$, Bairati I, Murry D, Allard J, et al. p53 and $\mathrm{Ki}-67$ as markers of radioresistance in head and neck carcinoma. Cancer. 2002 Feb 1;94(3):713-22.

34. Kumar M, Chatterjee K, Purkait SK, Samaddar D. Computer-assisted morphometric image analysis of cells of normal oral epithelium and oral squamous cell carcinoma. J Oral Maxillofac Pathol JOMFP. 2017 Apr;21(1):24-9. 
35. Bauer W, Mackenzie CD. Cancer Detection via Determination of Fractal Cell Dimension. :5.

36. Di Ieva A, Bruner E, Widhalm G, Minchev G, Tschabitscher M, Grizzi F. Computerassisted and fractal-based morphometric assessment of microvascularity in histological specimens of gliomas. Sci Rep. 2012;2:429.

37. Losa GA. The fractal geometry of life. Riv Biol. 2009 Apr;102(1):29-59.

38. Baish JW, Jain RK. Fractals and cancer. Cancer Res. 2000 Jul 15;60(14):3683-8.

39. Cross SS. Fractals in pathology. J Pathol. 1997 May;182(1):1-8.

40. Landini G. Fractals in microscopy. J Microsc. 2011 Jan;241(1):1-8.

41. Vakoc BJ, Lanning RM, Tyrrell JA, Padera TP, Bartlett LA, Stylianopoulos T, et al. Three-dimensional microscopy of the tumor microenvironment in vivo using optical frequency domain imaging. Nat Med. 2009 Oct;15(10):1219-23.

42. Klein K, Maier T, Hirschfeld-Warneken VC, Spatz JP. Marker-free phenotyping of tumor cells by fractal analysis of reflection interference contrast microscopy images. Nano Lett. 2013;13(11):5474-9.

43. Kirkby MJ. The fractal geometry of nature. Benoit B. Mandelbrot. W. H. Freeman and co., San Francisco, 1982. No. of pages: 460. Price: $£ 22.75$ (hardback). Earth Surf Process Landf. 1983;8(4):406-406.

44. Slobodrian RJ. Mathematical and Physical Fractals. Appl Math. 2014;05(12):1791800.

45. Ndiaye M. Combining Fractals and BoxCounting Dimension. Appl Math. 2021;12(09):818-34.

46. Wu KKS, Lahav O, Rees MJ. The LargeScale Smoothness of the Universe. Nature. 1999 Jan;397(6716):225-30.

47. Bassingthwaighte JB, Liebovitch LS, West BJ. Fractal Physiology [Internet]. New York, NY: Springer New York; 1994 [cited 2021 Nov 9]. Available from: http://link.springer.com/10.1007/978-14614-7572-9
48. Bergman DL, Ullberg U. Scaling properties of the placenta's arterial tree. J Theor Biol. 1998 Aug 21;193(4):731-8.

49. Peskin CS, McQueen DM. Mechanical equilibrium determines the fractal fiber architecture of aortic heart valve leaflets. Am J Physiol. 1994 Jan;266(1 Pt 2): H319328.

50. Weibel ER. Fractal geometry: a design principle for living organisms. Am J Physiol. 1991 Dec;261(6 Pt 1): L361-369.

51. Savage VM, Herman AB, West GB, Leu K. Using Fractal Geometry and Universal Growth Curves as Diagnostics for Comparing Tumor Vasculature and Metabolic Rate With Healthy Tissue and for Predicting Responses to Drug Therapies. Discrete Contin Dyn Syst Ser B. 2013 Jun;18(4).

52. Feder J. Fractal Surfaces. In: Feder J, editor. Fractals [Internet]. Boston, MA: Springer US; 1988 [cited 2021 Nov 9]. p. 212-28. (Physics of Solids and Liquids). Available from: https://doi.org/10.1007/978-1-48992124-6_13

53. Goutzanis L, Papadogeorgakis N, Pavlopoulos PM, Katti K, Petsinis V, Plochoras I, et al. Nuclear fractal dimension as a prognostic factor in oral squamous cell carcinoma. Oral Oncol. 2008 Apr;44(4):345-53.

54. Sedivy R, Windischberger C, Svozil K, Moser E, Breitenecker G. Fractal analysis: an objective method for identifying atypical nuclei in dysplastic lesions of the cervix uteri. Gynecol Oncol. 1999 Oct;75(1):7883.

55. Bedin V, Adam RL, de Sá BC, Landman G, Metze K. Fractal dimension of chromatin is an independent prognostic factor for survival in melanoma. BMC Cancer. 2010 Jun 5;10:260.

56. Bendler J. Fractals in science. J Stat Phys. 1995 Nov 1;81(3):857-60.

57. Rajesh L, Dey P. Fractal dimensions in urine smears: a comparison between benign and malignant cells. Anal Quant Cytol Histol. 2003 Jun;25(3):181-2. 
58. Peiss J, Verlande M, Ameling W, Günther RW. Classification of lung tumors on chest radiographs by fractal texture analysis. Invest Radiol. 1996 Oct;31(10):625-9.

59. Priebe CE, Solka JL, Lorey RA, Rogers GW, Poston WL, Kallergi M, et al. The application of fractal analysis to mammographic tissue classification. Cancer Lett. 1994 Mar 15;77(2-3):183-9.

60. Bianciardi G, Miracco C, De Santi MM, Luzi P. Differential diagnosis between mycosis fungoides and chronic dermatitis by fractal analysis. J Dermatol Sci. 2003 Dec;33(3):184-6.

61. Shabana AH, el-Labban NG, Lee KW. Morphometric analysis of basal cell layer in oral premalignant white lesions and squamous cell carcinoma. J Clin Pathol. 1987 Apr;40(4):454-8.

62. Shabana AH, el-Labban NG, Lee KW, Kramer IR. Morphometric analysis of suprabasal cells in oral white lesions. J Clin Pathol. 1989 Mar;42(3):264-70.

63. Giardina C, Caniglia DM, D'Aprile M, Lettini T, Serio G, Cipriani T, et al. Nuclear morphometry in squamous cell carcinoma (SCC) of the tongue. Eur J Cancer B Oral Oncol. 1996 Mar;32B(2):91-6.

64. Hannen EJ, van der Laak JA, Manni JJ, Pahlplatz MM, Freihofer HP, Slootweg PJ, et al. An image analysis study on nuclear morphology in metastasized and nonmetastasized squamous cell carcinomas of the tongue. J Pathol. 1998 Jun;185(2):17583.

65. Natarajan S, Mahajan S, Boaz K, George T. Morphometric Analysis of Nuclear Features and Volume-Corrected Mitotic Index in the Prognosis of Oral Squamous Cell Carcinoma. Oral Sci Int. 2009 Jan 1;6(2):8594.

66. Natarajan S, Mahajan S, Boaz K, George T. Prediction of lymph node metastases by preoperative nuclear morphometry in oral squamous cell carcinoma: a comparative image analysis study. Indian J Cancer. 2010 Dec;47(4):406-11.
67. Raju Ragavendra T, Rammanohar $M$, Sowmya K. Morphometric computerassisted image analysis of oral epithelial cells in normal epithelium and leukoplakia. J Oral Pathol Med Off Publ Int Assoc Oral Pathol Am Acad Oral Pathol. 2010 Feb;39(2):149-54.

68. Nandini DB, Subramanyam RV. Nuclear features in oral squamous cell carcinoma: A computer-assisted microscopic study. J Oral Maxillofac Pathol JOMFP. 2011 May;15(2):177-81.

69. Smitha T, Sharada P, Girish H. Morphometry of the basal cell layer of oral leukoplakia and oral squamous cell carcinoma using computer-aided image analysis. J Oral Maxillofac Pathol JOMFP. 2011 Jan;15(1):26-33.

70. Venkatesiah SS, Kale AD, Hallikeremath SR, Kotrashetti VS. Histomorphometric analysis of nuclear and cellular volumetric alterations in oral lichen planus, lichenoid lesions and normal oral mucosa using image analysis software. Indian J Dent Res Off Publ Indian Soc Dent Res. 2013 Apr;24(2):277.

71. Gadiwan M, Madhushankari G, Mandana D, Praveen S, Selvamani M, Pradeep D. Nuclear features in different grades of epithelial dysplasia in leukoplakia: A computer-assisted microscopic study. J Oral Maxillofac Pathol JOMFP. 2014 May;18(2):194-200.

72. Karino M, Nakatani E, Hideshima K, Nariai $\mathrm{Y}$, Tsunematsu K, Ohira $\mathrm{K}$, et al. Applicability of preoperative nuclear morphometry to evaluating risk for cervical lymph node metastasis in oral squamous cell carcinoma. PloS One. 2014;9(12):e116452.

73. Christopher V, Murthy S, Sr A, Singh S, Cp A, Shivaram SK, et al. Morphometry As a Diagnostic Tool for Potentially Malignant Lesions. J Clin Diagn Res JCDR. 2015 Dec;9(12):ZC22-25.

74. Gupta K, Gupta J, Miglani R. Computeraided morphometric analysis of oral leukoplakia and oral squamous cell 
carcinoma. Biotech Histochem Off Publ Biol Stain Comm. 2016;91(4):251-4.

75. Lennon FE, Cianci GC, Cipriani NA, Hensing TA, Zhang HJ, Chen C-T, et al. Lung cancer - a fractal viewpoint. Nat Rev Clin Oncol. 2015 Nov;12(11):664-75.
76. Pasqualato A, Lei V, Cucina A, Dinicola S, D’Anselmi F, Proietti S, et al. Shape in migration: quantitative image analysis of migrating chemoresistant HCT-8 colon cancer cells. Cell Adhes Migr. 2013 Oct;7(5):450-9. 